\title{
Producer Groups in the Czech Republic, Slovak Republic and Republic of Poland and their Market Share Potential
}

\author{
Pavel KOTYZA ${ }^{1}$, Andrzej HORNOWSKI ${ }^{2}$, Kateřina ELISOVÁ ${ }^{1}$. \\ ${ }^{1}$ Czech University of Life Sciences Prague, Prague, Czech Republic \\ \{kotyza,elisova\}@pef.czu.cz \\ ${ }^{2}$ Warsaw University of Life Sciences, Warsaw, Poland \\ andrzej_hornowski@sggw.pl
}

\begin{abstract}
Collective cooperation in rural areas is not just a phenomenon of the past. Marketing cooperatives in the agricultural sector are hotly debated worldwide. The main benefits of collective actions can include the benefits of size, sharing of knowledge and information, effective solution of local problems. To support collective actions the governments of all these three countries had decided to support the creation of marketing organisations after joining the EU. For that reason they provided public financial support for newly established producer groups and the allocation was realized on the basis of the Rural Development Programme with the aim, among others, to increase market share potential of individual farmers. Based on data obtained from paying agencies, it can be concluded that there were not established a large number of market-significant groups within individual states and commodity groups. Only in Slovakia, under the first programming period, there were groups with a significant share, i.e. a share above $15 \%$. In the next period, as in other countries, only cooperatives with a low share on the relevant market were supported. At the same time it was found that the rate of sales of active entities did not change significantly between Czech and Slovak entities. In most cases, sales are in the range of $€ 1-5$ million. In Poland, cooperatives with revenues above $€ 1$ million/year were established but there was also registered a significant number of cooperatives with sales below $€ 1$ million.
\end{abstract}

Keywords: Producer Groups, Poland, Czech Republic, Slovakia, EU, Support, Market Share, Rural Development.

\section{$1 \quad$ Introduction}

Collective cooperation in rural areas is not just a phenomenon of the past. Marketing cooperatives in the agricultural sector are hotly debated worldwide. In Europe, they played a key role in rural development in the first half of the twentieth century [7] and currently they are no less important in developing countries [10]. The importance of marketing cooperatives has been highlighted not only by the Organisation for Economic Co-operation and Development but also by other bodies, such as the Food and Agriculture Organisation of the United Nations (FAO). 
The main benefits of collective actions can include the benefits of size, sharing of knowledge and information, effective solution of local problems [14], increased market reach, better negotiation position, possibility of increasing the added value, increased confidence and greater influence potential [11].

The Czech Republic, Slovakia and Poland had experienced analogous historical development. However, the structure of subjects which are active in agriculture had retained certain characteristic features and specific differences. In the Czech Republic, economic subjects are typically farm areas far larger than the EU average [6], which means that they can keep their prices lower due to large quantities of production. In Poland, on the contrary, there is a large number of small farmers who farm relatively small plots, which places them in comparison with the Czech economic agricultural producers at a disadvantage. This situation has been caused by historical development, whereby in Poland, socialist collectivisation had never been completed to the same extent as in the Czech Republic. Slovakia, meanwhile, is in this respect somewhere in-between these two extremes, while being somewhat closer to the structure of Czech agriculture (see Tab. 1).

Table 1. Characteristics of agriculture in CZ, PL, SK. [4]

\begin{tabular}{lccc}
\hline & CZ & PL & SK \\
\hline Number of agric. holdings & 26,250 & $1,429,010$ & 23,570 \\
- of which utilised agriculture are < 5 ha (\%) & 18.6 & 54.4 & 58.9 \\
Utilised agriculture area per holding (ha) & 133.0 & 10.1 & 80.7 \\
Employment in agriculture (\%) & 2.9 & 10.5 & 2.9 \\
Agriculture, forestry and fishing (\% of GVA) & 2.5 & 2.5 & 3.8 \\
Agricultural goods output (million EUR) & $4,350.4$ & $1,888.2$ & $21,310.8$ \\
- of which: crop output (\%) & 63.5 & 48.6 & 62.3 \\
- of which: animal output (\%) & 36.5 & 51.4 & 37.7 \\
\hline
\end{tabular}

After joining the EU, the governments of all these three countries had decided to support the creation of marketing organisations. For that reason they provided public financial support for newly established producer groups and the allocation was realized on the basis of the Rural Development Programme with the aim, among others, to increase market share potential of individual farmers as it has been confirmed, that market concentration in food process industry leads toward positive influence on sectoral profitability [3]. This measure was enshrined in European legislation. Under the legislation, recognized producer groups were allowed to draw for the period of 5 years non-special-purpose funds, the level of which depended on the value of production supplied to the market, to a maximum of $€ 390,000$. However, with regard to the set conditions, the most advantageous way for the subject is to draw funds for revenue under $€ 1$ million. Revenues over $€ 1$ million have reduced support (e.g. in the first year from $5 \%$ to $2.5 \%$ ). 


\section{$2 \quad$ Aims and Methodology}

The main aim of this article is to compare in what manner the support led to market share increase in the Czech (CZ), Slovak (SK) and Polish (PL) Republics. The authors focus on evaluating the support provided during the first programming period of the Rural Development Programme, i.e., the evaluation of measures announced for the period of 2004-2006. In the subsequent programming period (2007-2013), no support in this area was provided in the Czech Republic, which is why the situation is evaluated only for Slovakia and Poland.

The following steps are followed to meet the set goal. First, the total market shares for the whole set of supported entities are determined. Then, on the basis of the application of the methodology, the subjects are evaluated in terms of their activity [8]. The actual classification is based on the examination of each subject in publicly available databases for signs that might indicate whether an entity can still carry out marketing activities and that does not contradict the given conditions of the programme after the end of state subsidies. In this way, 3 categories were created: (i) producer groups which have not been engaged in marketing activities any more, or contradicted the conditions of the programme; (ii) still functional producer groups; (iii) and entities for which it was not possible to find out the required amount of information. In the third step, the market share of subjects that could be defined as still functional producer groups was evaluated.

Based on above-mentioned classification, authors collected data on produced commodities, their sales and value of national production in particular commodities. Due to the fact, that groups received their support upon registered sales, information on sales were sourced from Czech (SZIF), Slovak (APA) and Polish (ARiMR) paying agency upon official request. Obtained data were analysed, processes and individual entities were qualified according the above-mentioned categories (i, ii, iii). Data on value of national annual production of certain commodities were gained in 2017 from Eurostat. From the data obtained, the market share was subsequently calculated:

Market share $=\frac{\text { sales registered by national paying organisation }}{\text { national production value at producer price measured by Eurostat }}$

Timeliness of registered sales data is limited by submitted payment requests. If, for example, the last payment is paid in the Czech Republic for 2010, the last available data comes from this year. In addition, it was not possible to use revenue data based on data from financial statements of the supported entities for several reasons: (i) it would not be possible to track revenues for individual commodities from the total revenue; (ii) not all the supported entities publish their financial statements in the Czech Republic and Slovakia; (iii) in Poland, financial statements are not available for small entities. 


\section{Results and discussion}

\subsection{The Czech Republic}

The state started with the support of the sales organizations in 1999 when the Ministry of Agriculture of the Czech Republic opened its first financial support. Once the Czech Republic joined the EU, the possibility of support with some contribution of the EU has come into force. Within this support, 208 entities were supported in total, and they were able to use the funds to support the creation of sales organizations between 2005 and 2010. Under the conditions set by the Ministry of Agriculture of the Czech Republic and the Government of the Czech Republic, a minimum number of members was set - two farming entities were allowed to form a producer group. Many entities used this option. According to available data, the average number of members per individual commodity oscillated between 2 and 5 members. Multiple groupings were an exception.

For the categories mentioned (see Tab. 2), the value of the output marketed for the period (i.e. 2005 2010) is between $€ 39,000$ and 565 million. The largest sales were achieved for swine bred for meat and cereals; followed by oil crops, poultry and cattle bred for meal. On the other hand, the lowest sales were achieved for sheep and goats kept for meal; followed by nurseries of fruit trees. For all monitored commodity groups, sales of the registered groups (208) for the entire period (i.e. 2005-2010) reached approximate value of $€ 1.79$ billion.

Table 2. Realized sales of the groups recognized by SZIF, RDP 04-06, Czech Republic. [5, 13]

\begin{tabular}{lcccc}
\hline \multicolumn{1}{c}{ Commodity } & No. of & \multicolumn{2}{c}{ EUR (2005-2010) } & $\begin{array}{c}\text { Market } \\
\text { share }(\%)\end{array}$ \\
\hline Swine bred for meat & 95 & $564,823,695$ & $2,472,950,000$ & 22.84 \\
Cereals & 118 & $548,729,096$ & $5,188,840,000$ & 10.58 \\
Oil crops & 122 & $279,072,211$ & $2,080,710,000$ & 13.41 \\
Poultry bred for meat & 46 & $232,263,967$ & $1,378,120,000$ & 16.85 \\
Cattle bred for meal & 75 & $106,256,757$ & $1,158,960,000$ & 9.17 \\
Potatoes & 12 & $22,924,514$ & $618,730,000$ & 3.71 \\
Medical, aromatic, spice plants & 9 & $17,730,017$ & $299,750,000$, & 5.91 \\
Flowers and ornamental trees & 1 & $12,814,037$ & $711,900,000$ & 1.88 \\
Nurseries of fruit trees & 1 & 578,198 & $7,330,000$ & 0.53 \\
Sheep and goats for meat & 7 & 39,043 & & \\
\hline
\end{tabular}

The registered groups achieved the highest market share in swine kept for meat, where registered sales for products accounted for $22.84 \%$ of total pig production in the Czech Republic. This high value, however, is based on the high number of the subjects (95) dealing with the trade in swine bred for meat. Consequently, this means that most of the listed groups did not achieved a significant market share in the commodity. Only 5 producer groups traded annual production worth more than $1 \% .3$ groups (OD Maso, OD Vrchovina, Žd'ár Obchodní družstvo) were an absolute 
exception because they surpassed the market share of $1.5 \%$, which meant sales of about $€ 10$ million. The shares of the other sales organizations ranged well below $1 \%$.

The producer groups reached the second highest market share in poultry bred for meat $(16.85 \%)$ cumulatively in 2005-2010. Despite the fact that 46 groups participated in the sale of $25 \%$ of the national production in 2007 and 2008, it should be noted that 40 entities supplied less than $1 \%$ of the national poultry production to the market. The most powerful groups were OD Dešná, Frobe and Drubos. These companies managed to realize more than $2 \%$ of the national poultry production in at least one of the monitored years.

Other important groups are oil crops and cereals. However, none of these commodities had any grouping that would realize a larger volume of produced cereals, respectively oil crops. While in the monitored period 118 groups supplied $10.58 \%$ of the Czech cereal production to the market, more or less a comparable number of groups (122) supplied $13.41 \%$ of oil crops to the market. In the case of cereals, no supported sales organization marketed cereals worth more than $1 \%$ of the production. In the case of oil crops, only one group was found - OD Třebič. For other commodity groups, the situation is similar, i.e. most of the registered groups did not realize more than $1 \%$ of the production on the market.

With regard to the proportion of sales to the total production of the commodity group, it is necessary to highlight the company HASINA, which between 2006 and 2010 marketed products worth between $€ 2-4$ million a year, in the group of medical and aromatic plants. However, the company has publicly identified itself as a trader in hops. The achieved sales would, for example, account for $8 \%$ of the value of hops produced in the Czech Republic in 2010.

Table 3. Share $(\%)$ of the active groups on agricultural production of a given commodity group, Czech Republic. [5, 8, 13]

\begin{tabular}{lcccccccccc}
\hline & $\mathbf{0 6}$ & $\sum^{1}$ & $\mathbf{0 7}$ & $\sum^{1}$ & $\mathbf{0 8}$ & $\sum^{1}$ & $\mathbf{0 9}$ & $\sum^{1}$ & $\mathbf{1 0}$ & $\sum^{\mathbf{1}}$ \\
\hline Swine bred for meal & 0.04 & 1 & 0.36 & 6 & 0.47 & 6 & 0.56 & 6 & 0.44 & 6 \\
Poultry bred for meal & 0.26 & 2 & 1.31 & 2 & 1.21 & 2 & 1.31 & 2 & 1.61 & 2 \\
Cattle bred for meal & 0.26 & 1 & 1.07 & 5 & 1.86 & 5 & 1.45 & 5 & 1.26 & 5 \\
$\begin{array}{l}\text { Medical, aromatic, spice } \\
\text { plants }\end{array}$ & - & - & 0.18 & 1 & 0.10 & 1 & 0.09 & 1 & 0.10 & 1 \\
$\begin{array}{l}\text { Cereals } \\
\text { Oil crops }\end{array}$ & 0.70 & 5 & 0.76 & 10 & 0.83 & 9 & 2.14 & 10 & 1.26 & 10 \\
\hline
\end{tabular}

${ }^{1}$ The number of groups that provided data to the paying agency for the given year

After classification of the individual producer groups it can be stated for the given date that out of the 208 subjects only 15 groups are considered as active, 184 were cancelled or did not meet the basic criteria and for 9 it was impossible to find relevant information about their activities. The above-mentioned more important groups $(O D$ Maso, OD Vrchovina, Obchodni družstvo Žd'ár, Frobe, Drubos, HASINA and OD Dešná) have been cancelled, have not continued in their activities, or it has not been possible to obtain information about their activities. As shown in Tab. 3, the concentration of supply was not achieved to a large extent in 15 active entities. Most 
producer groups did not achieve a market share of $1 \%$ on the relevant market, which can be seen as insignificant in terms of supply concentration. In 2010, the entities had the highest share in oil crops $(2.29 \%)$, but this value is made up of 13 entities. The most significant share was achieved by $O D$ Trebíc , which delivered goods worth almost

$€ 3.8$ million $(0.9 \%)$ to the market. For poultry kept for meal, only 2 producer groups delivered to the market around $1.6 \%$ of the national production. However, this situation was significantly affected by the performance of OD Dynin, which in 2010 added to the market $1.42 \%$ of the value of the produced poultry bred for meal ( $€ 3.5$ million).

\subsection{Poland}

The different structure of Polish agriculture is mainly due to different historical developments during the communist regime, where collectivization was not completed and a large number of farmers continued to produce individually, coordinated by the state apparatus through the state-controlled supply, marketing and processing cooperatives. After 1989, these cooperatives went through a complicated period, forced to sell off most of the property, and at the same time lost most of their members [2]. A national support policy for the creation of producer groups should lead to reverse integration. It has been applied continuously and without major changes since 1999 when it was financed by the SAPARD programme. After 2004, this policy has become a part of the Polish rural development policy (PROW) funded by EU funds. During the 1st programming period, 95 entities were supported, in the following - 1253 entities, and the programme continues also in period 2014-20.

Table 4. Realized sales of the cooperatives recognized by ARiMR, PROW 2004, Poland. [1, 5]

\begin{tabular}{|c|c|c|c|c|}
\hline \multirow{2}{*}{ Commodity } & \multirow{2}{*}{$\begin{array}{l}\text { No. of } \\
\text { groups }\end{array}$} & \multicolumn{2}{|c|}{ EUR (2005-2011) } & \multirow{2}{*}{$\begin{array}{c}\text { Market } \\
\text { share (\%) }\end{array}$} \\
\hline & & Reg. sales & Production & \\
\hline Swine & 30 & $232,279,154$ & $17,558,640,000$ & 1.32 \\
\hline Cereals and oil crops & 37 & $228,730,531$ & 25926460000 & 0.88 \\
\hline Milk & 7 & $135,011,492$ & $20,269,100,000$ & 0.67 \\
\hline Poultry & 7 & $68,934,458$ & $10,682,130,000$ & 0.65 \\
\hline Eggs & 3 & $31,991,721$ & $5,498,680,000$ & 0.58 \\
\hline Flowers and ornamental trees & 2 & $27,435,680$ & $874,970,000$ & 3.14 \\
\hline Tobacco & 3 & $15,923,249$ & $268,010,000$ & 5.94 \\
\hline Potatoes & 2 & $12,004,913$ & $6,071,730,000$ & 0.20 \\
\hline Sugar beet & 1 & $6,502,518$ & $2,500,740,000$ & 0.26 \\
\hline Cattle & 2 & $6,058,681$ & $6,581,520,000$ & 0.09 \\
\hline Hops & 1 & $4,198,971$ & $101,930,000$ & 4.12 \\
\hline
\end{tabular}

During the 1st monitored period, 95 supported subjects supplied goods worth $€ 769$ million. Most subjects registered for the sale of cereals and oil crops (37), pigs (30). Other commodities were represented in minority terms (see tab. 4). However, given the market share achieved, none of these 67 groups reached market share above $1 \%$. 
The greatest share in swine was achieved by the cooperative Lubawska Spółdzielnia Producentów Trzody "LUB-TUCZ", which marketed swine worth $€ 6.8$ million in $2010(0.3 \%)$. Other supported groups had a share of the swine market in the range of $0.03-0.1 \%$. Of the 30 supported cooperatives, there are still 16 active ones. Lubawska Spótdzielnia Producentów Trzody "LUB-TUCZ" still continues in its activities. In the case of cereals and oil crops, 24 cooperatives do not continue to operate. Of the 13 remaining entities, none of them achieves shares more than $0.13 \%$ of the Polish production. Registered revenues of the entities range between $€ 1-3$ million. For dairy cooperatives, only one ceased its activity. Other cooperatives registered sales in the range of $€ 1-10$ million, which would correspond to $0.035-0.2 \%$ of the Polish milk production.

After classification of 95 subjects, 44 were still characterized as active. After deducting the inactive groups, the rest of the 44 entities added to the market goods worth $€ 473.3$ million. As shown in Tab. 5, the overall market share of the still active registered sales on the relevant market at the Polish paying agency (ARiMR) is less than $1 \%$. The exceptions are Vitroflora and Zrzeszenie Plantatorów Tytoniu Proszowice-Opatkowice. Vitroflora, focused on flowers and ornamental trees, steadily recorded sales of $€$ 4-6 million in the monitored period, i.e. 3.2-4.3\% of the Polish value of flower and ornamental tree production between 2007 and 2011. The cooperative Plantatorów Tytoniu Proszowice-Opatkowice, the smallest of the 3 supported tobacco-supplying cooperatives, is still active. The value of the production delivered to the market increased steadily over the monitored period, exceeding

$€ 1$ million, thus increasing the market share to $2.89 \%$

Table 5. Share $(\%)$ of the active groups on agricultural production of a given commodity group, PROW 04-06, Poland. [1, 5, 8]

\begin{tabular}{lcccccccccccc}
\hline & $\mathbf{0 6}$ & $\sum^{\mathbf{1}}$ & $\mathbf{0 7}$ & $\sum^{\mathbf{1}}$ & $\mathbf{0 8}$ & $\sum^{\mathbf{1}}$ & $\mathbf{0 9}$ & $\sum^{\mathbf{1}}$ & $\mathbf{1 0}$ & $\sum^{\mathbf{1}}$ & $\mathbf{1 1}$ & $\sum^{\mathbf{1}}$ \\
\hline Potatoes & - & - & 0.05 & 1 & 0.13 & 1 & 0.07 & 1 & 0.02 & 1 & 0.01 & 1 \\
Poultry & - & - & 0.25 & 2 & 0.46 & 2 & 0.43 & 2 & 0.18 & 2 & 0.16 & 2 \\
$\begin{array}{l}\text { Flowers, ornamental } \\
\text { trees }\end{array}$ & 0.28 & 1 & 3.82 & 2 & 3.43 & 2 & 4.62 & 2 & 4.52 & 2 & 3.34 & 1 \\
Milk & 0.49 & 3 & 0.68 & 5 & 0.90 & 6 & 0.85 & 5 & 0.82 & 5 & 0.45 & 3 \\
Cereals and oil crops & 0.10 & 3 & 0.37 & 12 & 0.71 & 13 & 0.70 & 13 & 0.50 & 10 & 0.36 & 9 \\
Swine & 0.67 & 10 & 1.18 & 16 & 1.27 & 16 & 1.22 & 16 & 0.92 & 10 & 0.38 & 6 \\
Cattle & - & - & 0.05 & 1 & 0.06 & 1 & 0.06 & 1 & 0.08 & 1 & 0.08 & 1 \\
Tobacco & 1.08 & 1 & 1.71 & 1 & 1.74 & 1 & 2.89 & 1 & - & - & - & - \\
Eggs & 0.46 & 2 & 0.54 & 2 & 0.61 & 2 & 0.52 & 2 & 0.66 & 2 & - & - \\
\hline
\end{tabular}

${ }^{1}$ The number of groups that provided data to the paying agency for the given year

Within the second programming period, 1253 entities were recognized for the sale of 19 different commodity groups. The highest number of cooperatives (Tab. 6) traded cereals and oil crops (457), poultry (276) and swine (275). From the values of the cumulative share of revenues for the period 2008-2014 it is clear that in Poland small producers integrated into small groups which have only a minor share on the domestic 
market. This is evidenced by the fact that despite the large number of cooperatives made for the purpose of cereals and oil crops sales, the total share of traded production of these crops for the whole monitored period was only $5.32 \%$ of the national production. This shows that the average cooperative supplied approximately $0.012 \%$ of the value of cereals and oil crops, which is less than at the groups funded from the PROW 04-06.

Table 6. Realized sales of the cooperatives recognized by ARiMR, according commodities, PROW 07-13, Poland. [1, 5]

\begin{tabular}{|c|c|c|c|c|}
\hline \multirow{2}{*}{ Commodity } & \multirow{2}{*}{$\begin{array}{l}\text { No. of } \\
\text { groups }\end{array}$} & \multicolumn{2}{|c|}{ EUR (2008-2014) } & \multirow{2}{*}{$\begin{array}{c}\text { Market } \\
\text { share (\%) }\end{array}$} \\
\hline & & Reg. sales & Production & \\
\hline Cereals and oil crops & 457 & $1,725,310,640$ & $32,633,780,000$ & 5.29 \\
\hline Poultry & 276 & $2,039,381,098$ & $14,224,300,000$ & 14.34 \\
\hline Swine & 275 & $949,476,277$ & $17,659,400,000$ & 5.38 \\
\hline Milk & 98 & $533,964,869$ & $23,104,620,000$ & 2.31 \\
\hline Cattle & 51 & $38,758,422$ & $7,394,540,000$ & 0.52 \\
\hline Potatoes & 28 & $90,322,447$ & $5,941,030,000$ & 1.52 \\
\hline Eggs & 16 & $82,608,649$ & $6,669,520,000$ & 1.24 \\
\hline Sugar beet & 15 & $57,867,112$ & $2,477,600,000$ & 2.34 \\
\hline $\begin{array}{l}\text { Flowers and ornamental } \\
\text { trees }\end{array}$ & 8 & $54,596,666$ & $1,041,700,000$ & 5.24 \\
\hline Energy crops & 7 & $3,810,849$ & - & \\
\hline $\begin{array}{l}\text { Products of organic } \\
\text { farming }\end{array}$ & 6 & $3,312,665$ & - & \\
\hline Tobacco & 4 & $14,282,799$ & $351,500,000$ & 4.06 \\
\hline $\begin{array}{l}\text { Sheep and goats (kept } \\
\text { for meal, wool) }\end{array}$ & 3 & $1,090,293$ & $44,930,000$ & 2.43 \\
\hline Hops & 2 & $3,113,874$ & $65,210,000$ & 4.78 \\
\hline Rabbits & 2 & $22,893,152$ & - & \\
\hline Honey, bee products & 2 & 461,573 & - & \\
\hline Horses (live, meat) & 1 & 489,665 & $201,110,000$ & 0.24 \\
\hline $\begin{array}{l}\text { Medical, aromatic, } \\
\text { spice plants }\end{array}$ & 1 & 922,300 & - & \\
\hline $\begin{array}{l}\text { Other animals kept for } \\
\text { the skin }\end{array}$ & 1 & 508,772 & - & \\
\hline
\end{tabular}

The highest share of revenues in the value of the national production (cumulatively for 2008- 2014) is monitored at the group of poultry producers. Their market share surpassed $14 \%$. From the point of view of the average group's share, the groups of hops producers $(2.7 \%)$, tobacco $(1.04 \%)$, sheep and goats $(0.87 \%)$ had the highest average market share for the whole monitored period as well. On the other hand, the group of cattle producers $(0.010 \%)$, cereals and oil crops $(0.012 \%)$ and swine $(0.019 \%)$ reached very low values.

At the same time, it has to be mentioned that the value of sales increased sharply in the last 3 years of the programme (i.e. between 2011 and 2013), when $60 \%$ of all new groups were established. In 2013, there is a high share of sales in poultry breeding (20.7\%), growing tobacco (15.92\%), cereals and oil crops (13.93\%) and producing 
swine for meat (9.64\%). Although these values within the agricultural sector may indicate a high degree of integration of individual producers into sales units, it is not possible to forget the large number of entities that made up such high stakes.

During the disbursement of the subsidy, the total turnover of the production delivered to the market increased (Tab. 7). It should be noted, however, that in the first year 102 applications were accepted, proving the turnover of agricultural products worth $€ 147.8$ million, which corresponded to $0.71 \%$ of the Total Production of Agricultural Industry. With new entities, this value is continually increasing. From the data available for 2013 (753 group), it is clear that the value of output delivered to the Polish market is constantly increasing, amounting to $€ 1.4$ billion, which corresponds to $6.24 \%$ of the Total Production of Agricultural Industry.

Among the most significant cooperatives for the commodity groups there are mainly Grupa producentów drobiu (poultry, sales in $2014-€ 20$ million) with a market share of $0.8 \%$, Grupa producentów mleka ekolowiczanka (milk, sales in 2014 $-€ 30$ million) with a market share of $1 \%$, Gobarto hodowca (swine, $€ 18.5$ million in 2014) and a share of $0.7 \%$, Wielkopolska Grupa Zbożowa (cereals and oil crops, $€$ 16.5 million in 2014) with a share of $0.4 \%$, Łukowskie Zrzeszenie Plantatorów Tytoniu

(tobacco, $€ 2.5$ million in 2014) with a share of 4.5\%, and Eggs Product Grupa Producentów Rolnych ( $€ 7.2$ million in 2014) with a market share of $0.8 \%$ on the Polish egg production.

Table 7. Share $(\%)$ of the active groups on agricultural production of a given commodity group, PROW 07-13, Poland. [1, 5, 8].

\begin{tabular}{|c|c|c|c|c|c|c|c|c|c|c|c|c|c|c|}
\hline & 08 & $\sum^{1}$ & 09 & $\sum^{1}$ & 10 & $\sum^{1}$ & 11 & $\sum^{1}$ & 12 & $\sum^{1}$ & 13 & $\sum^{1}$ & 14 & $\sum^{1}$ \\
\hline Potatoes & 0.37 & 4 & 0.28 & 4 & 0.71 & 9 & 0.96 & 13 & 2.59 & 20 & 2.75 & 20 & 2.90 & 17 \\
\hline Sugar beet & - & - & 0.71 & 3 & 1.52 & 4 & 1.64 & 7 & 3.83 & 11 & 4.30 & 12 & 2.20 & 8 \\
\hline Poultry & 0.70 & 4 & 3.25 & 19 & 5.30 & 32 & 8.37 & 57 & 14.06 & 89 & 17.74 & 131 & 18.25 & 155 \\
\hline Hops & - & - & 9.87 & 1 & 3.28 & 1 & 4.45 & 1 & 15.71 & 2 & 2.94 & 1 & 6.34 & 1 \\
\hline Equines & - & - & - & - & 0.23 & 1 & 0.63 & 1 & 0.80 & 1 & 0.60 & 1 & - & - \\
\hline $\begin{array}{l}\text { Flowers, } \\
\text { ornamental trees }\end{array}$ & - & - & - & - & - & - & 0.79 & 1 & 4.11 & 3 & 5.32 & 4 & 7.12 & 4 \\
\hline Milk & - & - & 0.17 & 4 & 1.03 & 10 & 1.65 & 18 & 3.03 & 33 & 3.50 & 51 & 4.34 & 74 \\
\hline $\begin{array}{l}\text { Cereals and oil } \\
\text { crops }\end{array}$ & 0.77 & 26 & 2.02 & 67 & 3.01 & 106 & 3.61 & 158 & 5.61 & 220 & 7.52 & 251 & 6.05 & 257 \\
\hline Sheep and goats & - & - & 0.99 & 1 & 1.05 & 1 & 1.52 & 1 & 3.03 & 2 & 2.42 & 2 & 1.54 & 1 \\
\hline Swine & 0.68 & 13 & 1.35 & 27 & 1.99 & 40 & 3.04 & 59 & 5.32 & 87 & 7.32 & 124 & 10.87 & 166 \\
\hline Cattle & - & - & - & - & 0.09 & 3 & 0.17 & 7 & 0.42 & 14 & 1.06 & 31 & 1.24 & 35 \\
\hline Tobacco & - & - & - & - & - & - & - & - & 2.10 & 1 & 12.82 & 3 & 11.53 & 4 \\
\hline Eggs & 0.29 & 1 & - & - & 0.16 & 1 & 0.29 & 2 & 0.97 & 4 & 1.58 & 6 & 3.64 & 13 \\
\hline
\end{tabular}

${ }^{1}$ The number of groups that provided data to the paying agency for the given year

Polish groups face one significant problem - size. Only few groups reached sales above $1 \%$ of the Polish production of a given commodity. Also many groups 
marketed goods in value of tenth or thousandth percent of the national production with sales lower than $€ 1$ million.

\subsection{The Slovak Republic}

Under the programme of the first programming period (Rural Development Plan), there were registered producer groups for 9 commodity groups. In the second programming period, there were registered producer groups for 6 commodity groups. Compared with the Czech Republic, it is clear that there are larger groups in Slovakia. To a large extent, this is influenced by the structure of economic subjects. While most entities in the Czech Republic are registered as Inc. (55\%), in Slovakia, mainly cooperatives with a minimal number of members ( 5 natural persons or 2 legal entities) are registered. In Slovakia, therefore, it was not an exception that the groups (mainly in the first period) had more than 10 members; one entity even covered 73 producers in the tobacco trade. In the second period, the number of members is reduced, often to a minimum number (5).

Within the first programming period, 34 entities were registered (see Tab.8). Milk sales, i.e. commodity that requires immediate realization and processing, generated $37.4 \%$ of all sales ( $€ 206$ million). In terms of importance, milk was followed by the sale of cereals, poultry and eggs, potatoes, swine. These 5 groups accounted for $94.8 \%$ of the registered sales revenue of the Slovak paying agency (APA). Other commodities were represented only marginally.

Table 8. Realized sales of the producer groups recognized by APA, according commodities, PRV 04-06, Slovakia. [5, 12]

\begin{tabular}{lcrrc}
\hline \multicolumn{1}{c}{ Commodity } & $\begin{array}{c}\text { No. of } \\
\text { groups }\end{array}$ & \multicolumn{2}{c}{ EUR (2005-2010) } & $\begin{array}{c}\text { Market } \\
\text { Reg. sales }\end{array}$ \\
& 8 & $206,248,004$ & $1,539,680,000$ & 13.4 \\
\hline Milk & 12 & $123,608,727$ & $2,282,780,000$ & 5.4 \\
Cereals & 2 & $99,840,139$ & $1,069,060,000$ & 9.3 \\
Poultry and eggs & 4 & $47,656,057$ & $195,560,000$ & 24.4 \\
Potatoes & 3 & $45,543,519$ & $1,037,240,000$ & 4.4 \\
Swine kept for meat & 2 & $15,658,105$ & $897,640,000$ & 1.7 \\
Oil cops and legumes & 1 & $7,795,449$ & $8,730,000$ & 89.3 \\
Hops & 1 & $3,739,545$ & $52,140,000$ & 7.2 \\
Sheep (for meat, milk, wool) & 1 & $1,443,637$ & $1,230,000$ & 117 \\
Tobacco & & & & \\
\hline
\end{tabular}

Slovchmel', the only hops-producing group under this subsidy programme, boasts one of the most important business shares of all supported entities in all the rated states. The share of realized production in total production of Slovakia exceeded $89 \%$. Slovchmel' appears to be stabilized, with $€ 1.3$ million in 2016 , which corresponds to the registered values of the paying agency. Odbytové družstvo Pestovatelov Tabáku was to carry $117 \%$ of Slovak tobacco production. Although this figure is probably distorted, it can be seen from Eurostat that Odbytové družstvo Pestovatelov Tabáku carried out most of the produced tobacco in the SR during the monitored period. 
However, this fact is of no relevance to the evaluation of the programme, as the cooperative ceased its activity even within 5-year support.

Table 9. Share (\%) of the active groups, RDP 04-06, Slovakia. [5, 8, 12]

\begin{tabular}{lcrrrrrrrrrrr}
\hline & $\mathbf{0 5}$ & $\Sigma^{1}$ & $\mathbf{0 6}$ & $\Sigma^{1}$ & $\mathbf{0 7}$ & $\Sigma^{1}$ & $\mathbf{0 8}$ & $\Sigma^{1}$ & $\mathbf{0 9}$ & $\Sigma^{1}$ & $\mathbf{1 0}$ & $\Sigma^{1}$ \\
\hline Milk & 7.11 & 4 & 11.32 & 5 & 12.12 & 5 & 11.82 & 5 & 9.14 & 5 & 1.89 & 1 \\
Cereals & 0.47 & 1 & 2.54 & 4 & 2.69 & 4 & 1.71 & 4 & 2.05 & 4 & 1.50 & 3 \\
Oil crops and legumes & - & - & 2.06 & 1 & 1.37 & 1 & 1.82 & 1 & 1.53 & 1 & 1.43 & 1 \\
Sheep (meat, milk, wool) & 3.57 & 1 & 9.31 & 1 & 10.79 & 1 & 7.65 & 1 & 11.96 & 1 & - & - \\
Potatoes & 5.83 & 1 & 18.87 & 3 & 21.21 & 3 & 30.14 & 3 & 37.73 & 3 & 23.36 & 2 \\
\hline
\end{tabular}

${ }^{1}$ The number of groups that provided data to the paying agency for the given year

With regard to other commodities, the groups had a high market share for potatoes, milk or poultry and eggs (see Tab. 9). Especially for eggs, it is necessary to highlight the position of the Ovogal Farm, which held a market share of about $20 \%$ in the monitored period. A total of 8 cooperatives were devoted to milk sales, which accounted for $13.4 \%$ of the value of the milk production. Individual sales entities achieved different results. While 4 smaller dairy sales groups accounted for about $1 \%$ of the Slovak production, 4 larger entities reached a share of between $2 \%$ and $5 \%$. In terms of milk, 3 cooperatives have ceased their activities, 5 are still active. The most significant share is reached by ODM - odbytové družstvo mlieka (2.9\% in 2009), Odbytové družstvo sever (2.5\%) and Výrobno odbytové družstvo Mliečny východ (2\%); their shares did not change significantly during the monitored years.

Four groups were created due to potato sales, which in turn traded $24.4 \%$ of the Slovak potato production. Similarly to milk, half of the group had a low annual market share (2-3\%), while the remaining two groups, Zemiakarské $O D$ and Zeleninárska spoločnost', družstvo, jointly realized $34 \%$ of the potato production in Slovakia in 2009.

In terms of cereals, the most important is ODO - Odbytové družstvo obilnín Trnava, with registered sales of $€ 4$ million (1\%), other groups sold cereals for around $€ 1$ million a year. Only one group (OOV Zempol - družstvo) with a share of $1.5 \%$ ( $€$ 2.5 million, 2010) and total revenues of $€ 2.5$ million in 2016 remained active for oil cops and legumes.

Table 10. Realized sales of the producer groups recognized by APA, PRV 07-13, Slovakia. $[5,12]$

\begin{tabular}{lrrrc}
\hline \multicolumn{1}{c}{ Commodity } & \multicolumn{1}{c}{$\begin{array}{c}\text { No. of } \\
\text { groups }\end{array}$} & \multicolumn{2}{c}{ EUR (2008-2013) } & Market \\
& 28 & $319,894,246$ & $3,068,030,000$ & 10.4 \\
share (\%)
\end{tabular}


For the second programming period (Tab. 10), no group achieved a market share above $15 \%$. Of the 60 funded groups, the largest amount focused on the sale of cereals (28). Although the total share of sales of cereal production is more than $10 \%$, due to the number of groups, their individual market power is negligible. OD obilniny KOSTRIN could be considered the most powerful group, which in 2013 made $1.15 \%$ of the Slovak production, but it was cancelled in 2014. In 2012, the smallest sales cooperative produced less than $€ 1$ million in production, which would correspond to the value of the produced cereals in the amount of $0.13 \%$. Out of 28 cooperatives, there are still 5 active ones with sales between $€ 1$ and 3.5 million $(0.2-0.6 \%)$. For milk, for which 16 groups were registered, the situation is similar. 8 groups no longer work. The most significant share on the milk market was reached by OD mlieka Levice $(3.35 \%$ in $2013, € 8.8$ million), with other groups reaching a market share of around $1 \%$.

Within other commodities, compared to the Czech Republic and Poland, they managed to create entities that achieved an interesting market share. E.g. OD Dvory realized $2.84 \%$ of swine bred for meat; OD Jevišovice realized $2.31 \%$ of oil crops and legumes. However, like most of the registered and supported groups, these have been abolished. Of the total number of 60 registered and financed groups, only 17 are active today. They supply milk, cereals, oil crops and legumes on the market (Tab. 11).

Table 11. Share (\%) of the active groups, RDP 04-06, Slovakia $[5,8,12]$

\begin{tabular}{lrrrrrrrrrrrr}
\hline & 08 & $\Sigma^{1}$ & \multicolumn{1}{c}{09} & \multicolumn{1}{c}{$\Sigma^{1}$} & \multicolumn{1}{c}{10} & $\Sigma^{1}$ & \multicolumn{1}{c}{11} & $\Sigma^{1}$ & \multicolumn{1}{c}{12} & $\Sigma^{1}$ & 13 & $\Sigma^{1}$ \\
\hline Milk & 5.28 & 6 & 10.46 & 8 & 10.70 & 8 & 10.46 & 8 & 10.21 & 8 & 4.46 & 2 \\
Cereals & 0.97 & 2 & 1.33 & 4 & 2.09 & 5 & 2.02 & 5 & 1.98 & 5 & 0.56 & 2 \\
Oil crops and legumes & 1.48 & 1 & 1.77 & 2 & 2.48 & 3 & 2.64 & 3 & 2.32 & 3 & 0.93 & 2 \\
\hline
\end{tabular}

${ }^{1}$ The number of groups that provided data to the paying agency for the given year

\section{Conclusions}

Based on data obtained from paying agencies, it can be concluded that there were not established a large number of market-significant groups within individual states and commodity groups. Only in Slovakia, under the first programming period, there were groups with a significant share, i.e. a share above $15 \%$. In the next period, as in other countries, cooperatives with a low share on the relevant market were supported. At the same time, it is possible to see a significant trend in the establishing and abolishing of the producer groups. In all three countries, the number of abolished entities was higher than $50 \%$. In the Czech Republic, $88 \%$ of the funded entities were closed, in Slovakia it was $60 \%$ cancelled in the first period and $70 \%$ of the subjects in the second programming period. In Poland, $54 \%$ of the entities do not continue from the first period, and 1253 cooperatives were registered under the 2007-2013 Rural Development Programme, and the number of abolished cooperatives will significantly rise after 2018 when draw of 5 years funds ends. 
At the same time it was found that the rate of sales of active entities did not change significantly between Czech and Slovak entities. In most cases, sales are in the range of $€ 1-5$ million. In Poland, cooperatives with revenues above $€ 1$ million / year were established but there was also registered a significant number of cooperatives with sales below $€ 1$ million. At the same time, it is possible to monitor a certain top in the range of purchases, and it is worth $€ 3-5$ million. Only exceptions exceed this limit. This fact can only be attributed to the pragmatic performance of the entities which reached the maximum contribution $(€ 390,000)$ in trades at $€ 3$ million / year.

For minor groups of producers, it is meaningful to establish second-generation producer groups. In the case of the Czech Republic / Slovakia / Poland, it would be commodity-oriented umbrella associations that would support the interests of all small producer groups. It seems that, as in the Czech Republic and Slovakia, the number of producer groups is quite stabilized; low amount of the groups will not necessarily lead to the need for such umbrella organizations. However, in Poland, where there are tens and even thousands of small producer groups with minimal sales, such umbrella bodies would make sense. They would further strengthen the position of Polish farmers towards the government and the agri-food chain. Although the support of such bodies has been included into the Rural Development Programme 2014-2020 by the European Commission, unfortunately in the framework of the Polish Rural Development Programme 2014-2020 the support for the establishment of such entities has not been applied. A further wave of producer groups' abolishment can be expected, as they do not have a significant market share in their current configuration, so their economic advantage can end for farmers after receiving the last support payment.

Establishing and supporting the formation of producer groups make sense. In all three countries, there is still a group of farmers (mostly small family farmers, see Tab. 1) who are disadvantaged towards demand-side oligopsonic groups. Farmers bargaining position is therefore significantly worse and market integration could lead to the settlement of agricultural commodities market.

Acknowledgements. This contribution was supported from funds provided by National Science Centre Poland under PRELUDIUM project no. 2015/17/N/HS4/01550.

\section{References}

1. Agencja Restrukturyzacji i Modernizacji Rolnictwa (ARiMR): Data on of producer groups in Poland. Email communication (2014/11/25).

2. Boguta, W., Gumkowski, Z., Martynowski, M.: Spółdzielczość wiejska jako jedna z głównych form wspólnego gospodarczego działania ludzi. Krajowa Rada Spółdzielcza, Warsaw (2014).

3. Blažková, I., Dvouletý, O.: Drivers of ROE and ROA in the Czech Food Processing Industry in the Context of Market Concentration. AGRIS on-line Papers in Economics and Informatics 9(3), 3-14 (2017), DOI: 10.7160/aol.2017.090301. 
4. European commission: Agriculture in the European Union and the Member States Statistical factsheets, https://ec.europa.eu/agriculture/statistics/factsheets_en, last accessed 2017/10/26

5. Eurostat: Economic Accounts for Agriculture - Values at Current Prices, http://appsso.eurostat.ec.europa.eu/nui/show.do?dataset=aact_eaa01\&lang=en, last accessed 2017/10/26.

6. Hornowski, A., Kotyza, P.: Does size matters for creating income and value added? Case study of individual farmers in the Czech Republic and Poland using FADN data. In: Agrarian Perspectives, Proceedings of the 26th International Scientific Conference, 116122. Czech University of Life Sciences Prague, Prague (2017).

7. Hůlka, A.: Zemědělské družstevnictví. Československá akademie zemědělská, Prague (1931).

8. Kotyza, P.: Zhodnocení opatření programu rozvoje venkova podporující vznik nových odbytových organizací v zemědělství v České, Slovenské a Polské republice, dissertation theses. Czech University of Life Sciences Prague, Prague (2016).

9. Kotyza, P., Tomšík, K.: Effects of Public Support on Producer Groups establishment in the Czech Republic and Slovakia. Agris on-line Papers in Economics and Informatics 6(2), 34-47 (2014), ISSN: 1804-1930.

10. Ortmann, G., King, R. P.: Agricultural Cooperatives II: Can They Facilitate Access of Small-Scale Farmers in South Africa to Input and Product Markets?. Agrekon 46 (2), 219244, (2007), DOI: 10.1080/03031853.2007.9523769.

11. Penrose-Buckley, Ch.: Producer Organisations: A Guide to Developing Collective Rural Enterprises. Oxfam, Oxford (2007).

12. Pôdohospodárska platobná agentura (APA), Data on producer groups in Slovakia, Email communication $(2014 / 07 / 01)$.

13. Státní zemědělský a intervenční fond (SZIF), Data on producer groups in The Czech Republic, Email communication (2014/08/18).

14. Vanni, F.: Agriculture and Public Goods. Springer Dordrecht Heidelberg, London (2014). 